\title{
PREVALENCE OF OLDER DRIVERS IN BRAZIL: RESULTS FROM VIGITEL 2018
}

\section{Prevalência de motoristas idosos no Brasil: resultados do Vigitel 2018}

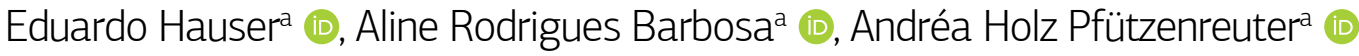

OBJECTIVE: To estimate the prevalence of Brazilian older adults who drive a car/ride a motorcycle, according to sociodemographic characteristics. METHODS: This cross-sectional study uses data from the 2018 Surveillance System for Risk and Protective Factors for Chronic Diseases by Telephone Survey (Vigitel). The prevalence of drivers was determined by an affirmative answer to the following question: “Do you drive a car, motorcycle and/or other vehicle?". RESULTS: Among the 15333 individuals aged

$\vdash \quad 65$ and over living in Brazilian capitals and the Federal District, the overall prevalence of drivers was $28.73 \%(95 \% \mathrm{Cl} 27.22-$ 30.29) and was higher among men (53.37\%; 95\% Cl 50.45 - 56.28), those with higher education (65.44\%; 95\%Cl 61.98 - 68.75), and individuals aged 65 to 69 years (35.7\%; 95\%Cl $33.06-38.61)$. Among the regions of Brazil, prevalence varied from 35\% (Midwest and South) to approximately 22\% (North and Northeast). Florianopolis (42.2\%; 95\%Cl $38.05-46.47$ ) and Palmas (40.32\%; $95 \% \mathrm{Cl} 32.74$ - 48.38) were the cities with the highest prevalence of older drivers. CONCLUSIONS: Characteristics such as sex, age group, region, and state capital of residence affect the prevalence of older drivers. Our results contribute to knowledge about how older adults choose to move around in large Brazilian cities, enabling proposal of strategies to improve the quality of this population's displacement.

KEYWORDS: aged; automobile driving; social indicators.

OBJETIVO: Estimar a prevalência de idosos brasileiros que dirigem carro/motocicleta, de acordo com características sociodemográficas. METODOLOGIA: Trata-se de estudo transversal realizado com dados do Sistema de Vigilância de Fatores de Risco e Proteção para Doenças Crônicas (Vigitel 2018). A prevalência de motoristas foi determinada pela resposta positiva à questão: “O(A) sr.(a) dirige carro, moto e/ou outro veículo?”. RESULTADOS: Entre os 15333 indivíduos de 65 anos ou mais, residentes nas capitais brasileiras e no Distrito Federal, a prevalência de motoristas foi de 28,76\% (IC95\% 27,22 - 30,29), sendo maior entre os homens (53,37\%; IC95\% 50,45 - 56,28), naqueles com maior escolaridade (65,44\%; IC95\% 61,98 - 68,75) e nos indivíduos de 65 a 69 anos (35,79\%; IC95\% 33,06 - 38,61). Entre as regiões do Brasil, a prevalência variou de 35\% (centro-oeste e sul) a, aproximadamente, $22 \%$ (norte e nordeste). As capitais com maior percentual de idosos motoristas foram Florianópolis (42,20\%; IC95\% 38,05 - 46,47) e Palmas (40,32\%; IC95\% 32,74 - 48,38). CONCLUSÕES: Características como sexo, faixa etária, região e capitais do Brasil afetam a prevalência de motoristas. Espera-se que os resultados apresentados aqui possam contribuir para o conhecimento de como os idosos escolhem se locomover nas grandes cidades brasileiras, permitindo propor estratégias para melhorar a qualidade de deslocamento dessa população.

PALAVRAS-CHAVE: idoso; condução de veículo; indicadores sociais.

aniversidade Federal de Santa Catarina - Florianópolis (SC), Brazil.

Correspondance data

Eduardo Hauser - Rua Waldemar Ouriques, 992 - CEP: 88090-051 - Florianópolis (SC), Brazil. E-mail: ehauser07@gmail.com

Received on: 07/23/2020. Accepted on: 10/20/2020

https://doi.org/10.5327/Z2447-212320202000089 


\section{INTRODUCTION}

Among the significant challenges arising from population aging, maintenance of autonomy, independence, and social participation stand out. ${ }^{1}$ Mobility, or movement, is essential in all its forms for individuals to remain active and healthy. ${ }^{2}$ Mobility is needed to perform activities of daily living such as working, physical activity, and shopping and leisure activities, and to access services and engage in social participation, which are all factors inherent to the autonomy and engagement of non-institutionalized individuals., ${ }^{2,3}$

Although older people, especially the oldest among them, are at greater risk of being involved in traffic collisions, ${ }^{4}$ driving and walking are older people's leading forms of mobility in their neighborhoods, especially in regions where access to public transport is poor. ${ }^{5}$ Data from the 2013 Survey of Basic Municipal Information (Pesquisa de Informações Básicas Municipais) $)^{6}$ showed that $96 \%$ of Brazilian cities lacked transportation planning: less than $1 \%$ of municipalities had a metro; $2.5 \%$ had trains; $38 \%$ had municipal buses; and in $67.7 \%$, vans were providing public transport. Moreover, by the start of 2019, only 14 capitals had drawn up mobility plans. ${ }^{7}$ This precarious public service and lack of planning may be reflected in higher numbers of people using a private motorized vehicle, probably as a driver.

In common with what has been seen in high-income countries, ${ }^{8}$ between 2005 and 2012, the number of older people ( $\geq 61$ years) able to drive in Brazil increased by approximately $11 \%$, reaching 3.6 million. ${ }^{9}$ The increase in the number of drivers in this age group is consistent with the trend of an aging population. In 2017, the number of older adults in Brazil was approximately 30.2 million, an $18 \%$ higher proportion than in 2012 ( $\mathrm{n}=25.4$ million). ${ }^{10}$ In 2016, the United States had about 42 million older adults licensed drivers, an increase of $56 \%$ compared to $1999 .{ }^{8}$ In Japan, the number of driver's licenses increased, especially among those aged 75 and over, to the point that it was 200\% higher in 2017 than in $1997 .{ }^{9}$

Sociodemographic characteristics such as sex, age, schooling, and geographic area, affect motorized mobility. ${ }^{11}$ Men tend to be the majority of drivers, both among Europeans ${ }^{12}$ and North Americans. ${ }^{13}$ The prevalence of older drivers reduces with increasing age ${ }^{13,14}$ and those with less schooling are less likely to keep driving. ${ }^{14}$

Despite the importance of driving as an element of mobility, no population studies have addressed any aspect of mobility using vehicles (or driving habits) among Brazilian older adults. Since Brazil is a country with continental dimensions, the marked environmental, cultural, demographic, and socioeconomic differences in different regions can have different repercussions on driving. Knowing the characteristics of
Brazil's older adults who use a car or motorbike contributes to understanding of urban mobility in capital cities and of how older people move about in their daily lives. This study aimed to estimate the prevalence of Brazilian older adults who drive a car or motorcycle, according to sociodemographic characteristics.

\section{METHODS}

This cross-sectional study uses data from the 2018 Surveillance System for Risk and Protective Factors for Chronic Diseases by Telephone Survey (Vigitel). Vigitel is an annual survey, which has been conducted in Brazil since 2006. The sampling procedures aim to obtain probabilistic samples of the adult population ( $\geq 18$ years old), residing in households served by at least one fixed-line home phone, in each of the Brazilian state capitals of the 26 Federation Units and the Federal District. Detailed information about the sampling process and instruments has been published previously ${ }^{15}$ and will be summarized briefly below.

From January to December 2018,172 800 calls were made, identifying 73648 eligible telephone lines, and 52395 interviews were completed. The team responsible for the interviews consisted of 40 interviewers, four supervisors, and two coordinators. Sampling was conducted in two stages. In the first stage, at least 5000 lines were drawn for each city. This draw was carried out systematically and stratified using postal codes (CEP), based on the register of fixed-line telephone numbers. One hundred and eighty-nine thousand telephone lines were initially drawn. In the second stage, adults residing in households selected were identified and drawn. This step was performed after identification, at the households served by the lines drawn, of those eligible for the system. Disabled lines, commercial and non-residential lines, and those at which there was no response after six call attempts on different days and at different times were excluded. After these steps, one adult resident ( $\geq 18$ years old) was chosen for interview from among all adults living in the household. ${ }^{15}$

This study used interview data from individuals aged 65 and over. The prevalence of drivers was identified using the following question: "Do you drive a car, motorcycle and/or other vehicles?" (Yes/ No). We present the prevalence of drivers, and their respective $95 \%$ confidence intervals $(95 \% \mathrm{CI})$ according to sex (male; female), age group (65 to 69; 70 to $74 ; 75$ to $79 ; 80$ to 84 , and 85 years or over) and education, in years of study ( 0 to 8 years; 9 to 11 years; 12 years or more). We also present the prevalence rates for the country and for the geographic regions and the capital cities of the states of Brazil plus its Federal District. Analyses were performed 
using R software version 3.5.2, using the Survey package, considering sample weightings (pesorake).

The present study used secondary data, with no identification of subjects, following the ethical principles established in National Health Council Resolution 510, of April 7, 2016. The Vigitel project was approved by the Ministry of Health's National Human Research Ethics Commission (CAAE: 65610017.1.0000.0008). ${ }^{15}$

\section{RESULTS}

In 2018, the Vigitel survey interviewed 15338 individuals aged 65 and over, five of whom did not answer the question related to driving status. Therefore, the sample analyzed in the present study consisted of 15333 respondents. Among the interviewees, 4770 (28.76\%; 95\%CI 27.22 - 30.29) reported being drivers. The data in Table 1 show that although the number of older women is higher than men, the prevalence of drivers was higher among men (53.37 vs. $12.82 \%)$. The prevalence of drivers was lower in the older age groups and higher among older people in the group with highest educational level.

The Brazilian region with the highest prevalence of older drivers was the South $(95 \%$ CI 33.38 - 38.11), followed by the Midwest $(95 \%$ CI $32.80-37.98)$ and the Southeast (95\%CI $27.02-32.49)$. The North (95\%CI $18.60-24.46)$ and the Northeast (95\%CI $21.24-24.57$ ) had prevalence rates close to $20 \%$ (Figure 1 ).
As shown in Table 2, Florianópolis (42.20\%) and Palmas (40.32\%) were the state capitals with the highest prevalence rates of older drivers. Cities that were notable for low proportions of drivers among older people were Belém (16.56\%), Salvador (18.41\%), and Recife (18.75\%). The prevalence of female drivers was only higher than $20 \%$ in Florianópolis (24.49\%), Vitória (21.03\%), and

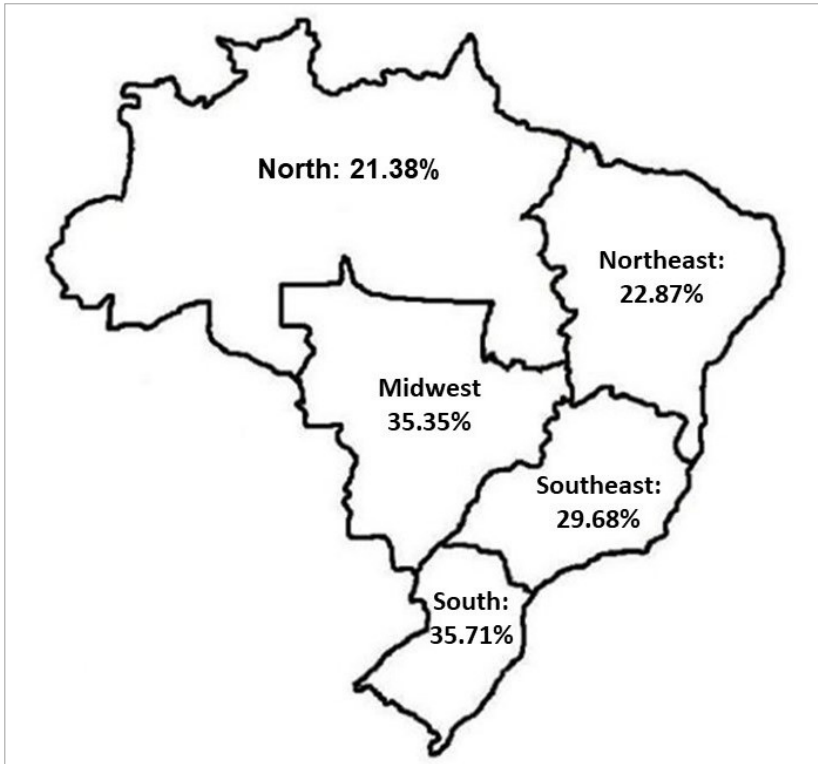

Figure 1. Percentage of older people who drive $(\geq 65$ years), according to the major geographic regions of Brazil $(n=15333)$.

Table 1. Prevalence rates of older drivers ( $\geq 65$ years), according to sex, age group, and schooling. ( $n=15333$ ).

\begin{tabular}{|c|c|c|c|}
\hline & $\begin{array}{c}\text { Sample } \\
\mathbf{n}\end{array}$ & $\begin{array}{c}\text { Drivers } \\
\mathbf{n}\end{array}$ & $\begin{array}{c}\text { Drivers } \\
\%(95 \% \mathrm{Cl})\end{array}$ \\
\hline \multicolumn{4}{|l|}{ Sex } \\
\hline Male & 4602 & 2860 & $53.37(50.45-56.28)$ \\
\hline Female & 10731 & 1910 & $12.82(11.64-14.00)$ \\
\hline \multicolumn{4}{|c|}{ Age groups (years) } \\
\hline $65-69$ & 4897 & 1932 & $35.79(33.06-38.61)$ \\
\hline $70-74$ & 4158 & 1408 & 30.85 (27.94 - 33.91) \\
\hline $75-79$ & 3055 & 863 & $27.02(23.37-31.00)$ \\
\hline $80-84$ & 2042 & 395 & $18.72(15.72-22.14)$ \\
\hline 85 or over & 1181 & 172 & $12.97(9.80-16.97)$ \\
\hline \multicolumn{4}{|c|}{ Schooling (years)* } \\
\hline $0-8$ & 7865 & 1248 & $20.06(18.20-22.05)$ \\
\hline $9-11$ & 3829 & 1234 & $33.67(30.87-36.60)$ \\
\hline 12 or more & 3622 & 2283 & $65.44(61.98-68.75)$ \\
\hline
\end{tabular}

95\%Cl: 95\% confidence interval; ${ }^{*} 17$ missing observations. 
Table 2. Percentage of older people who drive (> 65 years) in the Brazilian state capitals plus the Federal District (FD), according to sex $(n=15333)$.

\begin{tabular}{|c|c|c|c|c|c|c|}
\hline \multirow{2}{*}{$\begin{array}{l}\text { State capitals } \\
\text { and FD }\end{array}$} & \multicolumn{2}{|r|}{ Men and women } & \multicolumn{2}{|r|}{ Women } & \multicolumn{2}{|r|}{ Men } \\
\hline & $n$ & $\%(95 \% \mathrm{Cl})$ & $\mathrm{n}$ & $\%(95 \% \mathrm{Cl})$ & $n$ & $\%(95 \% \mathrm{Cl})$ \\
\hline Aracaju & 172 & $27.68(23.50-32.28)$ & 55 & 7.89 (5.69 - 10.84) & 117 & $59.51(50.27-68.13)$ \\
\hline Belém & 115 & $16.56(12.15-22.17)$ & 48 & $6.47(4.49-9.24)$ & 67 & $28.65(19.40-40.10)$ \\
\hline Belo Horizonte & 235 & $34.59(30.75-38.65)$ & 75 & $15.20(11.93-19.16)$ & 160 & $60.50(53.43-67.16)$ \\
\hline Boa Vista & 85 & $36.74(28.64-45.67)$ & 33 & $18.32(12.18-26.62)$ & 52 & $58.82(43.30-72.76)$ \\
\hline Campo Grande & 231 & $32.18(28.40-36.21)$ & 79 & $13.70(10.69-17.40)$ & 152 & $56.91(49.81-63.74)$ \\
\hline Cuiabá & 156 & $29.56(24.93-34.66)$ & 54 & $10.27(7.44-14.02)$ & 102 & $59.95(50.03-69.12)$ \\
\hline Curitiba & 176 & $37.46(33.60-41.48)$ & 123 & $19.46(16.17-23.24)$ & 153 & $71.13(63.60-77.65)$ \\
\hline Florianópolis & 159 & $42.20(38.05-46.47)$ & 110 & $24.49(20.35-29.17)$ & 149 & $71.20(63.97-77.49)$ \\
\hline Fortaleza & 170 & $25.57(21.28-30.40)$ & 77 & $10.83(8.27-14.07)$ & 93 & $47.96(38.46-57.61)$ \\
\hline Goiânia & 233 & $37.57(33.43-41.91)$ & 93 & $17.70(14.37-21.60)$ & 140 & $65.06(57.41-72.00)$ \\
\hline João Pessoa & 220 & $30.53(25.87-35.61)$ & 98 & $10.96(8.59-13.88)$ & 122 & $57.72(48.08-66.80)$ \\
\hline Macapá & 92 & $28.16(21.60-35.80)$ & 32 & $8.66(5.77-12.82)$ & 60 & $49.44(36.35-62.60)$ \\
\hline Maceió & 162 & $19.26(15.31-23.94)$ & 64 & $7.08(4.94-10.04)$ & 98 & $38.53(29.29-48.68)$ \\
\hline Manaus & 89 & $20.35(14.90-27.14)$ & 42 & $7.24(4.75-10.89)$ & 47 & $38.16(26.03-51.97)$ \\
\hline Natal & 207 & $28.97(24.53-33.84)$ & 85 & $10.75(8.25-13.89)$ & 122 & $55.97(46.68-64.87)$ \\
\hline Palmas & 123 & $40.32(32.74-48.38)$ & 41 & $14.14(9.52-20.48)$ & 82 & $67.18(54.61-77.69)$ \\
\hline Porto Alegre & 310 & $32.48(29.18-35.96)$ & 132 & $16.20(13.46-19.37)$ & 178 & $61.69(54.82-68.11)$ \\
\hline Porto Velho & 123 & $20.61(16.40-25.57)$ & 45 & $9.05(6.18-13.06)$ & 78 & $39.30(29.24-50.35)$ \\
\hline Recife & 174 & $18.75(15.53-22.46)$ & 84 & $9.29(7.20-11.90)$ & 90 & $36.07(28.23-44.73)$ \\
\hline Rio Branco & 99 & $27.47(21.07-34.96)$ & 41 & 7.11 (4.57 - 10.09) & 58 & $48.65(36.44-61.02)$ \\
\hline Rio de Janeiro & 212 & $23.53(20.34-27.06)$ & 70 & $9.85(7.58-12.71)$ & 142 & $46.19(36.04-53.50)$ \\
\hline Salvador & 102 & $18.41(14.75-22.73)$ & 30 & $4.65(0.30-0.69)$ & 72 & $37.20(29.12-46.07)$ \\
\hline São Luís & 134 & $23.86(19.21-29.23)$ & 49 & $6.84(4.77$ - 9.69) & 85 & $46.23(36.89-55.85)$ \\
\hline São Paulo & 171 & $32.58(28.08-37.42)$ & 72 & $15.12(11.83-19.12)$ & 99 & $60.32(51.57-68.46)$ \\
\hline Teresina & 140 & $23.55(18.75-29.13)$ & 44 & $5.55(3.85-7.94)$ & 96 & $51.64(40.98-62.14)$ \\
\hline Vitoria & 254 & $35.04(31.31-38.97)$ & 123 & $21.03(17.63-24.87)$ & 131 & $63.29(55.37-70.55)$ \\
\hline Federal District & 226 & $36.38(31.83-41.20)$ & 111 & $20.41(16.61-24.81)$ & 115 & $59.43(50.15-68.07)$ \\
\hline
\end{tabular}

95\% Cl: 95\% confidence interval.

the Federal District (20.41\%). Salvador (4.65\%), Teresina (5.55\%), and Belém (6.47\%) were the capitals with the lowest prevalence rates of female drivers. The highest prevalence rates of older male drivers were observed in Florianópolis (71.20\%), Curitiba (71.13\%), and Palmas (67.18\%). Considerable differences were observed between capitals in the same region in the North and Northeast. In the North region, the prevalence of drivers in Belém was 16.56, compared to $40.32 \%$ in Palmas. In the Northeast region, there was a $10 \%$ difference between the rates in João Pessoa and Maceió.

\section{DISCUSSION}

Based on data from Vigitel 2018, this study estimated the prevalence of Brazilian older drivers ( $\geq 65$ years), according to sociodemographic characteristics. Approximately 29\% of older adults with a fixed-line phone, residing in Brazilian state capitals and the Federal District reported driving a motorized vehicle (car and/or motorcycle). The prevalence was higher among younger age groups, men, and individuals with more years of schooling. The results also revealed differences in the prevalence of drivers in broad geographic regions and between different state capitals (and the Federal District). 
The estimated prevalence of drivers in the present study was lower than rates in the United States and some European countries. ${ }^{13,16}$ Data from the United States Department of Transportation ${ }^{13}$ show that, in 2017, approximately $80 \%$ of individuals aged 65 and over were drivers. In 2008-2009, Canada, Germany, Spain, and Great Britain had percentages exceeding 70\%. ${ }^{16}$ Differences in the values of prevalence estimates were expected since these countries all have a higher Human Development Index (HDI) than Brazil. The studies were also different in terms of methods, including the sampling process.

The higher prevalence of male drivers and older adults with more years of schooling was consistent with the literature. ${ }^{13}$ These results can be explained, at least in part, by gender disparities in life span. Current cohorts of older women faced low levels of schooling, job opportunities in less qualified and profitable activities, and were generally educated for work at home or family salaried employment. ${ }^{17}$ Data from the 2013 National Health Survey (Pesquisa Nacional de Saúde) showed that schooling, participation in paid work, and income were lower for older women compared to their male peers, ${ }^{17}$ resulting in lesser need to travel, as well as greater difficulty in purchasing a car. Individuals with higher schooling levels have higher income ${ }^{18}$ and, consequently, better employment/retirement and higher purchasing power to acquire vehicles.

The reduction in the prevalence of drivers in line with advancing age was expected and is consistent with data from the United States. ${ }^{13,14}$ The leading causes of this decrease may be related to natural changes in the aging process, health conditions of the individual, and greater use of medications. These changes affect physical and cognitive limitations ${ }^{14}$ affecting the ability to drive.

According to the data, the Midwest (35.35\%), South (35.71\%), and Southeast (29.68\%) regions had the highest prevalence of older drivers. The high rate of older drivers in the Midwest region may be due to several factors, such as long distances to be covered, lack of adequate public transport, and improved income. According to data from the Brazilian Institute of Geography and Statistics (Portuguese acronym IBGE) ${ }^{19}$ the Midwest region underwent rapid growth in per-capita income between 2002 and 2016. However, there were no improvements in local infrastructure. Additionally, this region includes the Federal capital, where the result of urban planning was to make mobility dependent on vehicles. ${ }^{20}$ The metropolitan areas in the South and Southeast of Brazil tend to have higher population densities and higher rates of vehicle ownership and usage than the metropolitan regions of the North and Northeast. ${ }^{21}$
Moreover, the Southeast and South regions are the most economically advanced and have the highest schooling rates. The lower prevalence of older drivers in the Southeastern region, compared to the South and Midwest, was a result of the low prevalence of older drivers in the municipality of Rio de Janeiro. Certain characteristics, such as the topography and social contrasts of Rio de Janeiro, which are reflected in the population density and population distribution, may help to explain, in part, this lower percentage of drivers. Preexisting physical barriers channeled urban occupation of the city and the southern zone and the coast of Barra da Tijuca (west zone) became areas where the highest-income residents are concentrated. ${ }^{22}$ Added to this, the Center and the South Zone, both regions with better access to public transport and where it is easier to travel on foot or by bicycle,${ }^{23}$ have higher percentages of older adults (21\%) than the northern (15\%) and West regions (12\%), and the neighborhoods Copacabana (30\%), Flamengo (29\%), Ipanema, and Leblon (28\%) have particularly high proportions. ${ }^{24}$

The state capitals with the highest percentages of older drivers were Florianópolis (42.20\%), in the South region, and Palmas (40.32\%), in the North region. In Brazil, types of mobility are associated with regions' income and development indexes. ${ }^{25}$ Among other particularities, the quality of public transport influences the decision to drive, since older adults who live near bus stops are less likely to drive than those who live farther away. ${ }^{3}$ Florianópolis has high schooling rates and high income and has the highest HDI of the Brazilian capitals (0.84); while Palmas has the highest HDI of the state capitals in the North region $(0.788) .{ }^{26}$ However, it is important to note that Palmas has poor public transport. It was also designed as a city with wide and long streets and has the second-highest rate of urban mobility among Brazil's state capitals, ${ }^{27}$ which may favor the use of private vehicles. On the other hand, Florianópolis is the capital with the worst mobility rate index in the country, that is, the capital with the worst displacement and one with substantial irregularities and discontinuity of its trunk highways, which, supposedly, would not encourage use of cars. ${ }^{27}$

The cross-sectional design and self-report by participants could be considered a limitation of this study. The results only apply to Brazilians with fixed-line home phones, since inclusion of cellphones in the sampling process would increase the cost of data collection for Vigite ${ }^{28}$ and has not yet been adopted. The probabilistic sampling process is a positive aspect, allowing for extrapolation of the results. The Vigitel survey has validity and reproducibility for several indicators, presenting results similar to household surveys conducted in Brazil. ${ }^{29}$ 


\section{CONCLUSION}

In conclusion, prevalence rates of older drivers in Brazilian capitals are higher among males, younger age groups, and those with more years of schooling. Our results show differences in the prevalence of drivers between the major geographic regions and between different state capitals (and the Federal District), highlighting that, in general, the prevalence of older drivers was higher in more developed capitals and regions. As seen among adolescent drivers in Brazil, it seems possible to speculate about environmental effects, with driving linked to locations with more precarious public transport and greater distances to be covered..$^{30}$

Thus, these findings contribute to knowledge about the mobility choices of adults for moving around in large Brazilian cities, allowing proposal of strategies to improve this population's quality of displacement. Consideration should also be given to concerns about the way older adults plan to get around when they stop driving, so that they can remain socially participative and healthy, without, however, forgetting the possibility of chronic diseases, visual impairment, and physical and cognitive limitations in this population.

\section{CONFLICTS OF INTEREST}

The authors declare no conflict of interest.

\section{FUNDING}

Coordenação de Aperfeiçoamento de Pessoal de Nivel Superior - Brasil (CAPES) - Finance Code 001.

\section{AUTHORS' CONTRIBUTION}

E.H.: conceptualization, methodology, formal analysis, investigation, writing - review \& editing. A.R.B.: conceptualization, methodology, supervision, project administration, writing - review \& editing. A.H.P.: writing - review \& editing.

\section{REFERENCES}

1. World Health Organization. World report on ageing and health. Geneva: World Health Organization; 2015. Available from: http:// apps.who.int/iris/bitstream/10665/186463/1/9789240694811_eng. pdf?ua=1. Accessed on: Jul 11, 2018.

2. Satariano WA, Guralnik JM, Jackson RJ, Marottoli RA, Phelan EA, Prohaska TR. Mobility and aging: new directions for public health action. Am J Public Health. 2012;102(8):1508-15. https://dx.doi. org/10.2105\%2FAJPH.2011.300631

3. Hess DB, Norton JT, Park J, Street DA. Driving decisions of older adults receiving meal delivery: The influence of individual characteristics, the built environment, and neighborhood familiarity. Transp Res A Policy Pract. 2016;88:73-85. https://doi.org/10.1016/j.tra.2016.03.011

4. Antin JF, Guo F, Fang Y, Dingus TA, Perez MA, Hankey JM. A validation of the low mileage bias using naturalistic driving study data. J Safety Res. 2017;63:115-20. https://doi.org/10.1016/j.jsr.2017.10.011

5. Aronson L. Don't Ruin My Life - Aging and Driving in the 21st Century. N Engl J Med. 2019;380(8):705-7. https://doi.org/10.1056/ NEJMp1613342

6. Instituto Brasileiro de Geografia e Estatística. Perfil dos estados e municípios brasileiros. Brasil: Instituto Brasileiro de Geografia e Estatística; 2014. Available from: https://ww2.ibge.gov.br/home/ estatistica/economia/perfilmunic/2014/default.shtm. Accessed on: Jun 6, 2019.

7. Mobilize Brasil. Quase metade das capitais ainda não tem plano de mobilidade. Mobilize Brasil; 2019. Available from: https://www. mobilize.org.br/noticias/11463/quase-metade-das-capitais-aindanao-tem-plano-de-mobilidade-planmob.html. Accessed on: Sept 26, 2020

8. Matsuyama T, Kitamura T, Katayama Y, Hirose T, Kiguchi T, Sado J, et al. Motor vehicle accident mortality by elderly drivers in the superaging era. A nationwide hospital-based registry in Japan. Medicine. 2018;97(38):e12350. https://doi.org/10.1097/md.0000000000012350

9. Federação Nacional das Associações de DETRAN. Segurança no trânsito para a terceira idade. Brasil: Federação Nacional das Associações de DETRAN; 2013. Available from: http://fenasdetran. com/noticia/seguranca-no-transito-para-a-terceira-idade. Accessed on: Jun 19, 2019
10. Paradella R. Pesquisa Nacional por Amostra de Domicílios Contínua. Instituto Brasileiro de Geografia e Estatística; 2018. Avaliable from: https://agenciadenoticias.ibge.gov.br/agencia-noticias/2012agencia-de-noticias/noticias/20980-numero-de-idosos-cresce-18em-5-anos-e-ultrapassa-30-milhoes-em-2017. Accessed on: Sept 11, 2019.

11. Payyanadan RP, Lee JD, Grepo LC. Challenges for Older Drivers in Urban, Suburban, and Rural Settings. Geriatrics. 2018;3(2):14. https://doi.org/10.3390\%2Fgeriatrics3020014

12. Hajek A, Brettschneider C, Eisele M, Van den Bussche H, Wiese B, Mamone $\mathrm{S}$, et al. Prevalence and determinants of driving habits in the oldest old: Results of the multicenter prospective AgeCoDeAgeQualiDe study. Arch Gerontol Geriatr. 2019;82:245-50. https:// doi.org/10.1016/j.archger.2019.03.006

13. Federal Highway Administration (FHWA). Department of Transportation (US). Highway Statistics. Washington, D.C.: Federal Highway Administration; 2018. Available from: https://www.fhwa.dot.gov/ policyinformation/statistics/2018/dl20.cfm. Accessed on: Apr 1, 2020.

14. Kandasamy D, Betz ME, DiGuiseppi C, Mielenz T, Eby DW, Molnar LJ, et al. Self-reported health conditions and related driving reduction in older drivers. Occup Ther Health Care. 2018;32(4):363-79. https:// doi.org/10.1080/07380577.2018.1522681

15. Brasil. Ministério da Saúde. Vigitel Brasil 2018. Vigilância de fatores de risco e proteção para doenças crônicas por inquérito telefônico. Brasil: Ministério da Saúde; 2019. Availsable from: http:// portalarquivos2.saude.gov.br/images/pdf/2019/julho/25/vigitelbrasil-2018.pdf. Accessed on: Sept 10, 2019.

16. Sivak M, Schoettle B. Recent changes in the age composition of drivers in 15 countries. Traffic Inj Prev. 2012;13(2):126-32. https:// doi.org/10.1080/15389588.2011.638016

17. Castro CMS, Costa MFL, Cesar CC, Neves JAB, Sampaio RF. Influência da escolaridade e das condições de saúde no trabalho remunerado de idosos brasileiros. Cien Saude Colet. 2019;24(11):4153-62. https://doi.org/10.1590/1413-812320182411.05762018

18. Barros DS. Schooling and distribution of income between employees in the Brazilian economy: a comparative analysis of the public and private sectors of the years 2001 and 2013. Rev Econ Contemp. 2017;21(3):e172135. https://doi.org/10.1590/198055272135 
19. Instituto Brasileiro de Geografia e Estatística. Pesquisa Nacional por Amostra de Domicílios Contínua - PNAD Contínua. Brasil: Instituto Brasileiro de Geografia e Estatística. Available from: https://www. ibge.gov.br/estatisticas/sociais/trabalho/17270-pnad-continua. html?=\&t=o-que-e. Accessed on: Jun 6, 2019.

20. Martins ADAC, Lima Neto VC. Dependência do automóvel, o planejamento regional e Brasília. Universitas Arquit Com Soc. 2013;10(1):23-34. https://doi.org/10.5102/uc.v10i1.1982

21. Pereira RHM, Schwanen T. Commute time in Brazil (1992-2009): Differences between metropolitan areas, by income levels and gender. Brasília: IPEA; 2013. Available from: http://repositorio.ipea. gov.br/bitstream/11058/964/1/TD_1813a.pdf. Accessed on: Sept 25, 2018.

22. Mourão,BM. Percepções sobre o trânsito. In: Rio de Janeiro. Secretaria Municipal de Saúde. Subsecretaria de Atenção Primária, Vigilância e Promoção da Saúde. Superintendência de Promoção da Saúde. Segurança e Civilidade no Trânsito Urbano do Rio de Janeiro. Rio de Janeiro: SMS; 2014. 80 p. (Série D. Programas, Projetos e Relatórios). Available from: https://www.ucamcesec.com.br/wp-content/ uploads/2014/09/LivroTransito.pdf. Accessed on: Jun 21, 2020.

23. Associação Nacional de Transportes Públicos. Sistema de Informações da Mobilidade Urbana da Associação Nacional de Transportes Público. Relatório geral 2017. Associação Nacional de Transportes Públicos; 2020. Available from: http://files.antp.org.br/simob/sistemade-informacao-de-mobilidade-urbana-da-antp--2017.pdf. Accessed on: Jun 21, 2020.

24. Serviço de Apoio às Micro e Pequenas Empresas do Estado do Rio do Janeiro. Painel regional: Rio de Janeiro e bairros. Rio do Janeiro: SEBRAE/RJ; 2015. Available from: https://www.sebrae.com.br/Sebrae/
Portal\%20Sebrae/UFs/RJ/Anexos/Sebrae_INFREG_2014_CapitaIRJ. pdf. Accessed on: Jun 17, 2020.

25. Sá TH, Pereira RHM, Duran AC, Monteiro CA. Socioeconomic and regional differences in active transportation in Brazil. Rev Saude Publica. 2016;50:37. https://doi.org/10.1590/S15188787.2016050006126

26. Instituto de Pesquisa Econômica Aplicada. O índice de desenvolvimento humano municipal brasileiro. Brasil: Instituto de Pesquisa Econômica Aplicada; 2013. Available from: https://www.ipea.gov.br/portal/ images/stories/PDFs/130729_AtlasPNUD_2013.pdf. Accessed on: Mar 6, 2020.

27. Barros APBG, Medeiros VAS, Morais MP. Urban accessibility and spatial segregation in Brazilian cities: a configurational perspective. Brasil: IPEA; 2017. Available from: http://ipea.gov.br/portal/images/ stories/PDFs/TDs/ingles/td_227.pdf. Accessed on: Jul 21, 2020.

28. Bernal RTI, Malta DC, Claro RM, Monteiro CA. Effect of the inclusion of mobile phone interviews to Vigitel. Rev Saude Publica. 2017;51(Suppl. 1):15. https://doi.org/10.1590/s1518-8787.2017051000171

29. Malta DC, Iser BPM, Santos MAS, Andrade SSDA, Stopa SR, Bernal RTI, et al. Estilos de vida nas capitais brasileiras segundo a Pesquisa Nacional de Saúde e o Sistema de Vigilância de Fatores de Risco e Proteção para Doenças Crônicas Não Transmissíveis por Inquérito Telefônico (Vigitel) 2013. Rev Bras Epidemiol. 2015;18(Suppl. 2):68-82. https://doi.org/10.1590/19805497201500060007

30. Duarte EC, Garcia LP. Adolescent drivers in Brazil: prevalence and associated factors estimated from the National Adolescent Schoolbased Health Survey (PeNSE 2012). Rev Bras Epidemiol. 2014;17(Suppl. 1):3-16. https://doi.org/10.1590/1809-4503201400050002 